\title{
Gonadotrophic control of follicle growth in the ewe
}

\author{
A. S. McNeilly, H. M. Picton, B. K. Campbell* and D. T. Baird* \\ MRC Reproductive Biology Unit and *Department of Obstetrics and Gynaecology, University of \\ Edinburgh, Centre for Reproductive Biology, 37 Chalmers Street, Edinburgh EH3 9EW. UK
}

\begin{abstract}
Summary. Preovulatory follicle growth in the ewe is dependent on FSH although no precise relationship appears to exist between plasma concentrations of FSH and the number of preovulatory follicles which develop or ovulation rate. This may be related to a hitherto unrecognized influence of pulsatile $\mathrm{LH}$ on the growth of large follicles. Preovulatory follicle growth is dependent on the presence of basal amounts of LH, but pulsatile LH, while being essential to supply an increase in androgen substrate to the granulosa cells of the follicle, may also play a role in reducing the responsiveness of many large follicles to FSH, in particular during the preovulatory phase when plasma concentrations of FSH are reduced. Thus selection of the preovulatory follicle(s) may involve a previously unrecognized interaction between FSH and pulsatile $\mathrm{LH}$ secretion in which pulses of $\mathrm{LH}$ act in a negative rather than positive manner.
\end{abstract}

Keywords: FSH; LH; follicle growth; sheep

\section{Introduction}

In our review in 1981 (Baird \& McNeilly, 1981) we summarized the roles of FSH and LH in the control of preovulatory follicle growth in the ewe. The results to that date suggested that FSH was responsible for the growth of the follicle, and the reduction in plasma concentrations of FSH during the follicular phase of the cycle was responsible for the selection of the follicle destined to oyulate. The steroidogenic activity of the follicle was dependent on LH, which controlled the release from the theca of the follicle of androgens, which are subsequently converted to oestradiol by the aromatase enzyme, induced by $\mathrm{FSH}_{2}$ in the granulosa cells. Therefore, $\mathrm{LH}$ appeared to play little part in the selection of the preovulatory follicle, FSH alone being responsible. The control of FSH secretion therefore became of major importance and our understanding of this control was advanced considerably by the elucidation of the structure of inhibin, the 'specific' suppressor of FSH release. Our studies on the interactions of inhibin and oestradiol in the control of FSH secretion during the sheep oestrous cycle are reviewed by Baird et al. (1991). This paper will examine the evidence accumulated oyer the past I0 years on the role of FSH and LH in the control of follicle growth and steroid and inhibin secretion in relation to follicle selection.

\section{Follicular growth and selection}

Follicle growth and development is a continuum throughout the reproductive cycle in the ewe. The growth rate of follicles may vary between animals but does not appear to vary significantly between breeds, time of season or between seasons (Cahill \& Mauléon, 1980). Preovulatory follicles are therefore present at all times throughout the oestrous cycle and anoestrus and are equivalent in number to the ovulation rate of that breed (Cahill \& Mauléon, 1980; McNatty et al., 1984a, 1985a; 
Webb \& Gauld, 1985). The absence of ovulation during the luteal phase and anoestrus is related to a failure of exposure to an adequate amount of LH and the resultant failure of the follicle(s) to generate a preovulatory LH surge because ovulation can be induced during the luteal phase of the cycle (Thomas et al., 1987) and anoestrus (McNeilly \& Land, 1979; Martin \& Scaramuzzi, 1983; McNatty et al., 1984a) if an appropriate LH signal is given, although the resultant corpora lutea may not secrete normal amounts of progesterone.

In sheep, although the total duration of folliculogenesis (i.e. from growth initiation to ovulation) is thought to be about 6 months (Cahill \& Mauléon, 1980), the final stages of follicular growth are extremely rapid with the follicle taking about 5 days to grow from 0.5 to $2.2 \mathrm{~mm}$ in diameter (Turnbull et al., 1977) and a further 3-4 days to reach 4-5 mm (Turnbull et al., 1977; McNeilly, 1984). Although preovulatory follicles are present in the ovary throughout the oestrous cycle the ovulatory follicle appears to be derived from a pool of follicles greater than $2 \mathrm{~mm}$ in diameter at the time of luteolysis (McNatty et al., 1982; Driancourt et al., 1986; Webb et al., 1989). and emerges as a growing oestrogenic follicle within $10 \mathrm{~h}$ of luteolysis (McNatty et al., 1982). The ovary, however, has the ability to promote other follicles into the ovulatory role: reduction of the follicle population by unilateral ovariectomy (Findlay \& Cumming, 1977), electrocautery (Tsonis et al., 1984) or injection of bovine follicular fluid (McNeilly, 1984; Henderson et al., 1988) will only increase the time to ovulation if carried out during the last $24-36 \mathrm{~h}$ before the LH surge. In more prolific breeds, however, follicles greater than $3 \mathrm{~mm}$ in diameter at the time of luteolysis may continue to develop and be joined at the time of ovulation by follicles which increased in diameter from 2.5 mm (McNatty et al., 1986; Driancourt \& Fry, 1989).

The importance of gonadotrophins in follicle growth is dependent on the stage of follicle development. Total withdrawal of gonadotrophins as a result of hypophysectomy results in a failure of follicle development beyond $0.06-0.07 \mathrm{~mm}$ and an absence of antral follicle formation (Dufour et al., 1979). In the presence of basal LH and FSH, follicle growth is maintained but is dependent on continued gonadotrophic support. Thus, the abolition of the pulsatile secretion of LH and the $30-$ $50 \%$ reduction in the basal concentrations of FSH that result from active immunoneutralization of GnRH (McNeilly et al., 1986) or GnRH receptor downregulation by chronic treatment of ewes with a GnRH agonist (McNeilly \& Fraser, 1987) results in a failure of follicle development beyond $2.5 \mathrm{~mm}$ diameter. The failure to grow into preovulatory follicles appears to be related to the reduction in FSH rather than absence of LH pulses since a similar failure of follicle growth beyond $2.5 \mathrm{~mm}$ diameter occurred when plasma concentrations of FSH were suppressed specifically by treatment of ewes throughout the luteal phase with bovine follicular fluid (Hunter et al., 1988; J. M. Wallace, C. G. Tsonis, G. B. Martin \& A. S. MeNeilly, unpublished observations). In these animals pulsatile LH continued at a normal frequency and amplitude but did not maintain follicle growth (Wallace \& McNeilly, 1986).

During the normal follicular phase LH pulse frequency increases as a result of a decline in venous progesterone concentrations (Wallace et al., 1988; Picton 1989), while FSH declines as a result of the increase in the ovarian secretion of oestradiol and inhibin (Baird et al., 1990a). Although the ovulatory follicle grows under conditions of depressed FSH this follicle(s) still retains a dependence on FSH because profound decreases in the concentration of FSH, induced by oFF given $24 \mathrm{~h}$ after the induction of luteolysis when selection has occurred, results in a delay in ovulation that is associated with a marked decline in the ovarian secretion of oestradiol, inhibin and androgens, despite continued stimulation by $\mathrm{LH}$, that is consistent with the immediate induction of atresia of the ovulatory follicle (Baird et al., 1990b; Fig. 1). In contrast, removal of the pulsatile LH secretion by administration of a potent GnRH antagonist (Campbell et al., 1990a) or GnRH immunoneutralization (McNeilly et al., 1984) at the same stage of the cycle will prevent ovulation and inhibit ovarian steroid secretion but follicle growth is maintained as replacement of the $\mathrm{LH}$ stimulus results in immediate re-establishment of steroid secretion. These results support the concept that preovulatory follicle growth is dependent on FSH and that LH is required to stimulate thecal steroidogenesis. 
(a) Untreated (Ewe 0G17)

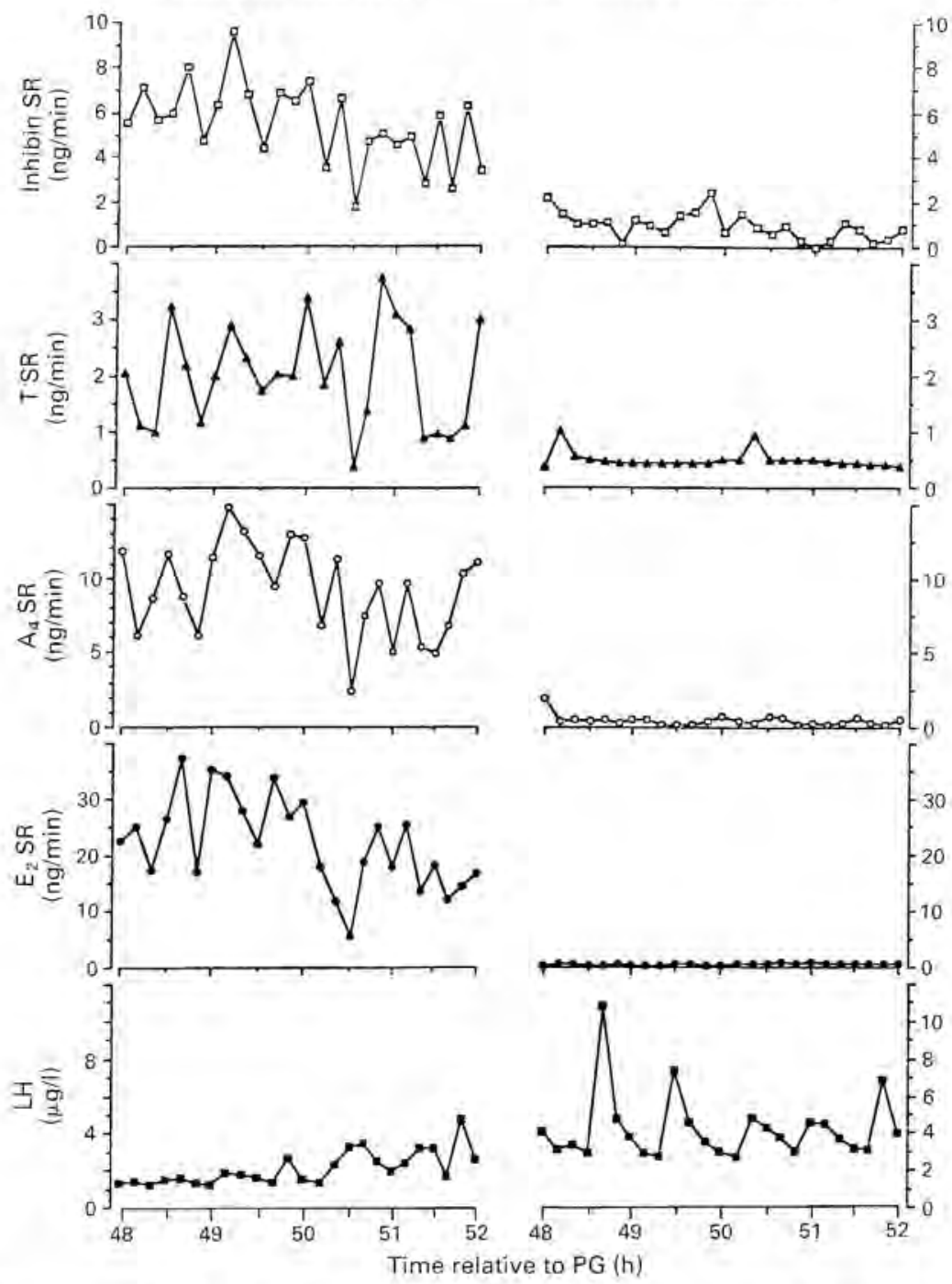

Fig. 1. Changes in the plasma concentration of LH and the ovarian secretion rate (SR) of inhibin, testosterone $(T)$, androstenedione $\left(A_{4}\right)$ and oestradiol $\left(E_{2}\right)$ during the late follicular phase 48-52 h after prostaglandin-induced luteolysis in an untreated ewe (a) and a ewe which received ovine follicular fluid ( $3 \mathrm{ml} \mathrm{s.c.)} 24$ and $36 \mathrm{~h}$ after prostaglandin. (From Baird et al., 1990a.)

\section{Relative roles of the gonadotrophins in the control of follicular growth}

The normal oestrous cycle

It has long been known that the injection of gonadotrophins such as PMSG (Robinson, 1959; Allen \& Stewart, 1978; Betteridge, 1981), and FSH-P (Burns-Biotech and Sigma; Monniaux et al,, 1983; Henderson et al., 1988) can lead to dose-related increases in ovulation rate. However, as these gonadotrophins have both LH and FSH activity it is unclear if one or the other, or both, of these activities are responsible for their actions. Only relatively recently has it been demonstrated that 
repeated injections or infusions of purified FSH can induce multiple ovulations (McNeilly, 1985; McNatty et al., 1985b; Henderson et al., 1988). Purified FSH has also been shown to increase the number of non-atretic antral follicles, increase the aromatase activity of antral follicles and negate the inhibitory effects of bovine follicular fluid on atresia (McNatty et al., 1985b). These observations, plus the observed lack of relationship between $\mathrm{LH}$ concentrations and ovulation rate (see Scaramuzzi \& Radford, 1983; Bindon et al., 1984), suggest that exogenous gonadotrophins of mixed activity, such as PMSG, act mainly through their FSH activity to increase ovulation rate. Presumably the mode of action of FSH and PMSG to increase ovulation rate centres on their ability to activate the granulosa cell aromatase enzyme systems and therefore increase oestradiol secretion (Dott et al, 1979; Hsueh et al., 1984; Henderson et al., 1985, 1987).

Although exogenous FSH can stimulate superovulation, the question still remains as to whether FSH is the major regulator of follicular growth in normal physiological situations. Several studies have sought to determine whether differences in ovulation rate, assumed to relate to differences in the number of preovulatory follicles that develop, are related to identifiable differences in the plasma concentrations of either LH or FSH. One widely used approach has involved the comparison of breeds with different ovulation rates. In the majority of these studies no differences in LH throughout the oestrous cycle have been observed (see Scaramuzzi \& Radford, 1983). Some reports suggest that FSH may be higher at some stages of the oestrous cycle in some breeds (Lahlou-Kassi et al., 1984; McNatty et al., 1985b, 1989) but the reports are not consistent and no clear relation between higher ovulation rate and higher FSH has emerged (Findlay \& Cumming, 1976; Cahill et al., 1981; Driancourt et al., 1988). There is limited evidence to suggest that the biological activity of secreted FSH, at least in the prolific Booroola Merino, may be altered (Bindon et al., 1984) and that this would not be detected by the radioimmunoassays currently available. Within the same breed of ewe plasma concentrations of FSH tended to be higher for 1-3 days before the onset of luteolysis in ewes subsequently having twin ovulations than in those having only a single ovulation (McNatty et al., 1985b). Similarly, reduced plasma concentrations of FSH occurring during the luteal and follicular phases in ewes in poor body condition are associated with a reduction in the number of preovulatory follicles and subsequent ovulation rate (Rhind \& McNeilly, 1986; McNeilly et al., 1987). In contrast, several treatments that are known to increase ovulation rate such as immunization against androgens (Scaramuzzi \& Hoskinson, 1984; Campbell, 1988) or against partly purified follicular fluid (Henderson et al., 1984; Cummins et al., 1986; Al-Obaidi et al., 1986) do not result in consistent increases in plasma FSH concentrations. Immunization against both oestrogens and androgens, however, invariably leads to increases in peripheral LH values (Scaramuzzi \& Hoskinson, 1984; Campbell, 1988). It is therefore clear from these observations that there is still little evidence to establish clearly that variations in the plasma concentrations of FSH are directly related to differences in preovulatory follicle growth in the normal oestrous cycle. This may relate to the wide variation in plasma concentrations of FSH between animals within the same breed which may obscure a direct relationship between preovulatory follicle growth and variations in plasma FSH values within an individual ewe. In addition, it is now clear that plasma concentrations of FSH vary in a reasonably consistent manner, excluding the well recognized decrease and increase during the preovulatory phase (Baird \& McNeilly, 1981). For example, plasma concentrations of FSH decrease on Days 3-4, increase on Days 6-8 and then fluctuate throughout the rest of the luteal phase until luteolysis and the onset of the follicular phase (Bister \& Paquay, 1983; Wallace \& McNeilly 1986; Campbell, 1988). Evidence is beginning to accumulate that these fluctuations in FSH may reflect the development and subsequent regression of large oestrogenic follicles throughout the luteal phase (A, S. McNeilly \& J. Wallace, unpublished observations; Campbell et al, 1990b) and that different ewes may have different patterns of follicular development throughout the luteal phase (Campbell, 1988), as has been observed in cattle (Savio et al., 1988; Sirois \& Fortune, 1988). Any comparison of changes in plasma concentrations of FSH must take this into account. Although it has been suggested that the second surge of FSH occurring after the preovulatory surge may be important in controlling subsequent ovulation rate 
(Cahill et al., 1981), this appears unlikely since the follicle(s) destined to ovulate probably only emerge and are selected within $48 \mathrm{~h}$ of the start of the preovulatory surge, some 14 days after the second surge.

Selection is thought to occur during the follicular phase (see above) and so the preovulatory period has been intensively studied. The number of follicles which grow during this period is clearly influenced by the amount of FSH available. Treatment of ewes with PMSG (Mauleon \& Mariana, 1977) or pure FSH (McNeilly, 1985; McNatty et al., 1985b; Henderson et al., 1988) from the time of onset of luteolysis results in a variable and uncontrollable increase in follicle growth and subsequent ovulation rate. The timing of the FSH stimulus in relation to the time of selection is also important as the increase in ovulation rate is greater if FSH treatment is initiated up to $24 \mathrm{~h}$ before the onset of luteolysis (Baird et al., 1984; McNatty et al., 1985b) but there is no effect if FSH is given within $24 \mathrm{~h}$ of the onset of the preovulatory surge (Henderson et al., 1988). An increase in follicle growth and ovulation rate also occurs in response to the rebound release of FSH after the end of the bFF suppression of FSH throughout the luteal phase (Wallace \& McNeilly, 1985; Wallace et al., 1985; Henderson et al., 1986). In this case the increase in ovulation rate is not excessive, a $100-200 \%$ increase, even though the plasma concentration of FSH occurring during this period of the rebound is of the same order as that achieved when reasonable amounts of exogenous FSH are injected into ewes which, in contrast, can result in a spectacular hyperstimulation of follicle development (McNeilly, 1985). It is therefore clear from these studies that FSH is a major determinant of follicular growth but the relative roles of $\mathrm{LH}$ and FSH in the control of folliculogenesis cannot be elucidated from these studies.

\section{Anoestrus}

No clear picture has emerged in relation to changes in the plasma concentrations of FSH throughout anoestrus and the lack of ovulation appears to be principally due to a lack of $\mathrm{LH}$, at least in the short term (see McNeilly et al., 1985). Ovulation of follicles that are present at the time of treatment can be achieved by the pulsatile injection of LH alone (McNeilly et al., 1982; McNatty et al., 1984b) or with a consistent frequency of pulsatile GnRH (McLeod et al., 1982a, b). Continued pulsatile treatment with $\mathrm{GnRH}$, but not LH results in continued follicle growth, ovulation and luteal function (McNatty et al., 1984b). Treatment with GnRH maintained the plasma concentrations of FSH, while LH treatment was associated with a reduction in FSH. These results support the concept that preovulatory follicle growth in anoestrus is dependent on FSH. Indeed, it is clear from studies on the induction of ovulation in anoestrus, particularly in sheep of the more seasonal breeds, that the proportion of ewes ovulating and forming a normal corpus luteum was signifcantly increased by concomitant treatment with FSH in at least 3 breeds of ewe when ovulation was induced with pulsatile LH (McNeilly et al., 1985; Wallace et al., 1986). Suppression of FSH by injection of bovine follicular fluid during the treatment of anoestrous ewes with pulsatile GnRH prevented ovulation (McLeod \& McNeilly, 1987), confirming the requirement for FSH for normal follicle growth during anoestrus (McNatty et al., 1985b; Hunter et al., 1988). Therefore, when ovulation is induced in the anoestrous ewe, it is probable that LH pulses act principally on the follicles that are already present, and do not induce the formation of new preovulatory follicles. This would explain the relatively low percentage of ewes which ovulate in response to LH pulses alone compared to the number ovulating when either GnRH pulses are given or when FSH is given together with LH (McNeilly et al., 1985; Wallace et al., 1986). In spite of these observations, the precise interaction between FSH and LH in controlling the number of preovulatory follicles which develop is unclear.

\section{The GnRH agonist model}

To address the question of the relative roles of LH and FSH in the control of follicular development, a model has been developed which involves the specific suppression of gonadotrophin 
secretion by a potent agonist of GnRH (McNeilly \& Fraser, 1987). Chronic treatment of ewes with GnRH agonist initially causes an increase in plasma concentrations of FSH and LH lasting for 3-6 days after which plasma concentrations of FSH fall to $40-50 \%$ of those in the normal luteal phase while $\mathrm{LH}$ values return to basal levels, are non-pulsatile and remain unresponsive to GnRH stimulation (Picton et al., 1990a). After 4-6 weeks of treatment, follicle growth beyond $2.5 \mathrm{~mm}$ is inhibited, providing an ideal model to assess the effects of FSH and $\mathrm{LH}$ alone or in combination on the control of preovulatory follicle growth. A major advantage of this model is that only the secretion of gonadotrophins is affected and the ovaries remain exposed to normal endogenous concentrations of all pituitary hormones other than $\mathrm{LH}$ and $\mathrm{FSH}$.

In this model the infusion of ovine FSH alone in the presence of basal concentrations but nonpulsatile secretion of $\mathrm{LH}$ resulted in a time-dependent increase in preovulatory follicle growth (Picton et al., 1990a). There was a time-dependent increase in the mean number and diameter of these follicles $>2.5 \mathrm{~mm}$ and an increase in the number which could be classified as oestrogenic ( $>$ I ng oestradiol/follicle $\mathrm{h}^{-1}$ in vitro) (Fig. 2). Injection of human chorionic gonadotrophin after $120 \mathrm{~h}$ of FSH infusion caused the majority of these large follicles to ovulate and form apparently normal corpora lutea (Picton et al., 1990a). In the absence of LH pulses the number of follicles which were classified as oestrogenic exceeded that seen during the luteal or follicular phase of the oestrous cycle (Fig. 2). This suggested that the absence of LH pulses may have allowed a greater number of oestrogenic follicles to develop for the given amount of FSH infused, further suggesting that LH pulses may reduce or interfere with the ability of FSH to induce preovulatory follicle growth, i.e. LH pulses may participate in the selection of the preovulatory follicle. To test this, during the period of FSH infusion, $\mathrm{LH}$ was injected as a bolus every $4 \mathrm{~h}$ in amounts sufficient to give either a small or large amplitude pulse equivalent to the extremes of LH pulse amplitude observed during the luteal phase of the cycle. The 4-h interval is equivalent to the mean $\mathrm{LH}$ pulse frequency during the mid-luteal phase in these ewes. Low amplitude $\mathrm{LH}$ pulses did not significantly alter the number of follicles $>2.5 \mathrm{~mm}$ or the proportion which were oestrogenic induced to develop during the FSH infusion (Fig. 3), although the maximum diameter of the follicles was reduced. In contrast, the number of follicles $>2.5 \mathrm{~mm}$ in diameter developing in response to FSH was reduced when large-amplitude pulses were given and none of these large follicles was oestrogenic (Fig. 3). In a further study the amplitude of the LH pulse was maintained at a constant level but the amount of FSH infused was increased such that the plasma concentrations of FSH ranged from 40 to $200 \%$ of normal mean luteal phase concentrations of FSH. The number of preovulatory follicles which developed was directly related to the plasma concentration of FSH and addition of LH pulses prevented follicle growth except at the highest plasma concentration of FSH (Table 1).

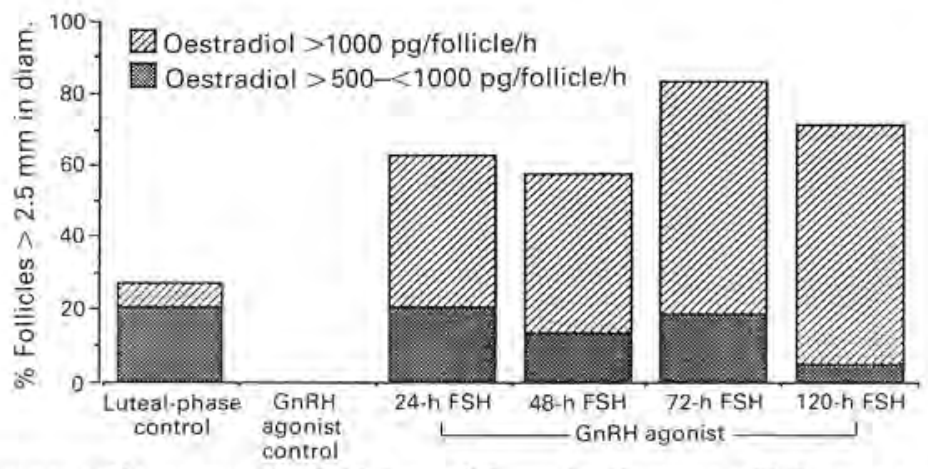

Fig. 2. Percentage of large ovarian follicles $>2.5 \mathrm{~mm}$ in diameter which secrete oestradiol (in vitro) in day-8 luteal-phase control ewes and in ewes treated with a GnRH agonist for 6 weeks to suppress FSH and LH and infused with ovine FSH for 24-120 h. Values are means \pm s.e.m. for each treatment group. (From Picton et al., 1990a). 


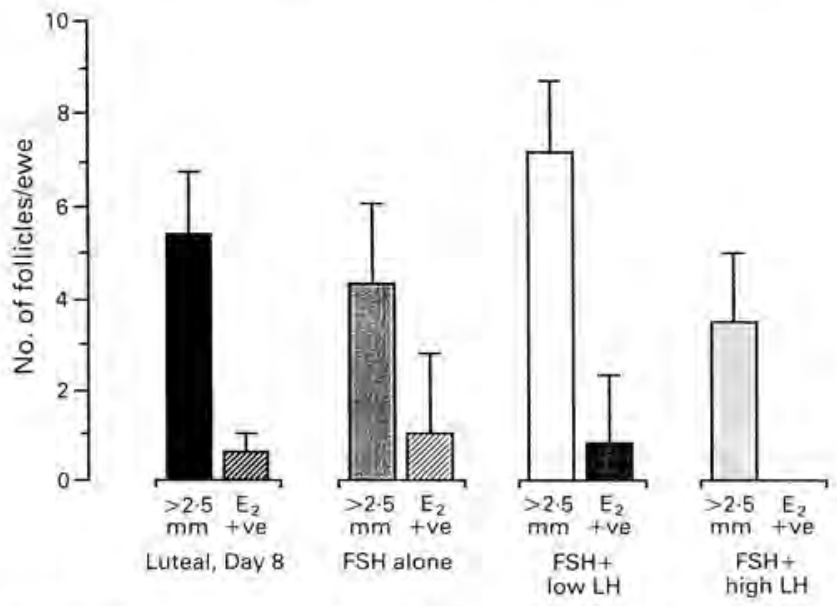

Fig. 3. The effect of LH pulse amplitude on the growth of follicles $>2.5 \mathrm{~mm}$ in diameter $(>2.5 \mathrm{~mm})$ and follicles classified as oestrogenic (secreting $>1000 \mathrm{pg}$ oestradiol $/ \mathrm{h}$ in vitro $\left(\mathrm{E}_{2}+\mathrm{ve}\right)$ ) induced by the infusion of ovine FSH for $72 \mathrm{~h}$ in ewes after treatment with a GnRH agonist for 6 weeks to suppress FSH and LH. Ovine LH was given i.v. as a bolus injection every $4 \mathrm{~h}$ throughout the period of FSH infusion. Values are means \pm s.e.m. for each treatment group and are compared to follicles in Day-8 luteal-phase control ewes. (Summarized from Picton (1989) and Picton et al. (1990a,b).)

Table 1. The effect of a constant pulse amplitude of LH on growth of follicles to $>2.5 \mathrm{~mm}$ in diameter induced by increasing the plasma concentration of FSH during a 72-h infusion of ovine FSH at a low, medium or high rate in ewes after treatment with a GnRH agonist for 6 weeks to suppress FSH and LH. (Summarized from Picton (1989) and Picton et al. $(1990 \mathrm{a}, \mathrm{b}))$

\begin{tabular}{|c|c|c|c|c|}
\hline \multirow[b]{2}{*}{ Treatment } & \multirow{2}{*}{$\begin{array}{l}\text { Rate of FSH } \\
\text { infusion }\end{array}$} & \multirow{2}{*}{$\begin{array}{l}\text { Plasma FSH } \\
(\mathrm{ng} / \mathrm{ml})\end{array}$} & \multicolumn{2}{|c|}{ No. of follicles $>2.5 \mathrm{~mm}$} \\
\hline & & & Without LH & With LH \\
\hline \multicolumn{5}{|l|}{ Luteal phase } \\
\hline Day 8 & - & $25 \cdot 9 \pm 5 \cdot 4$ & - & $5 \cdot 4 \pm 1.4^{*}$ \\
\hline \multirow[t]{4}{*}{ GnRH agonist } & - & $8 \cdot 2 \pm 0.1$ & 0 & $\overline{0}$ \\
\hline & Low & $14.1 \pm 1.5$ & $1.0 \pm 0.7$ & 0 \\
\hline & Medium & $30 \cdot 9 \pm 2 \cdot 3$ & $12.8 \pm 3.4$ & 0 \\
\hline & High & $62 \cdot 0 \pm 8.3$ & $23 \cdot 3 \pm 7 \cdot 1$ & $21 \cdot 5 \pm 5 \cdot 2$ \\
\hline
\end{tabular}

Values are mean \pm s.e.m.

Ovine LH was not (without LH) or was (with $\mathrm{LH}$ ) given i.v. as a bolus injection every $4 \mathrm{~h}$ throughout the period of FSH infusion. Results are compared to plasma FSH levels and number of follicles $>2.5 \mathrm{~mm}$ in diameter on Day 8 of the luteal phase of a normal oestrous cycle.

\section{Conclusions}

These results support the new concept that LH pulses may interfere with the ability of FSH to induce preovulatory follicle growth, but the effect is dependent both on the amplitude of the LH pulse and on the plasma concentration of FSH. However, while it is clear that LH pulses alone will not induce preovulatory follicle growth, FSH will only induce preovulatory follicle growth in the 
presence of basal concentrations of LH. Thus infusion of FSH was unable to stimulate follicle growth when LH was immunoneutralized with a specific LH antiserum (Picton, 1989).

The mechanism by which LH pulses interfere with FSH induction of preovulatory follicle growth is unclear. However, a role for increased androgen alone is unlikely since the non-atretic preovulatory follicles induced with FSH alone secrete large quantities of androgen (Picton et al., $1990 \mathrm{a}, \mathrm{b})$. An action of LH other than via steroids may therefore be involved. These results suggest that pulsatile $\mathrm{LH}$ secretion may play an active role in preovulatory follicle selection by altering the responsiveness of the growing follice to FSH and may act in concert with the decline in FSH secretion to enhance atresia in follicles deprived of FSH.

The continued support of the NIDDK, Bethesda, MD and NHPP, University of Maryland School of Medicine, USA, for supply of hormones is gratefully acknowledged. We thank Miss N. Anderson, W. Crow and Mr D. Heath for technical assistance. This work was supported in part by MRC programme Grant G426375. H.M.P. was supported by the Colin and Ethel Gordon Fellowship of the University of Edinburgh.

\section{References}

Allen, W.R. \& Stewart, F. (1978) The biology of pregnant mare serum gonadotrophin (PMSG). In Control of Reproduction in the Cow: Current Topics in Veterinary Medicine, pp. 50-72. Martinus Nijhoff, The Hague

Al-Obaidi, S.A., Bindon, B.M. Hillard, M.A. \& O'Shea, T. (1986) Suppression of ovine plasma FSH by bovine follicular fluid: neutralization by plasma from ewes immunized against an inhibin-enriched preparation from bovine follicular fluid. $J$ Endocr. 11, $1-5$

Baird, D.T. \& McNeilly, A.S. (1981) Gonadotrophic control of follicular development and function during the oestrous cycle of the ewe. I. Reprod. Fert., Suppl. 30, 119-133.

Baird, D.T., McNeilly, A.S., Wallace, J.M. \& Webb, R. (1984) Infusion of FSH increases ovulation rate in Welsh Mountain ewes. Proc. 5th Renier de Graaf Sympostum, Abstr. 13.

Baird, D.T., Campbell, B.K. \& McNeilly, A.S. (1990a) Ovine follicular fluid suppresses the ovarian secretion of androgens, oestradiol and inhibin. $J$. Endocr. (in press).

Baird, D.T., Campbell, B.K., Mann, G.E. \& MeNeilly, A.S. (1990b) The role of inhibin and oestradiol in the regulation of FSH secretion in the ewe. J. Reprod. Fert., Suppl. 43, 125-138.

Betteridge, K.J. (1981) An historical look at embryo transfer. J. Reprod, Fert. 62, 1-13.

Bindon, B.M., Piper L.R., Cummins, L.J., O'Shea, T., Hillard, M.A., Findlay, J.K. \& Robertson, D.M. (1984) Reproductive endocrinology of prolific sheep: studies of the Booroola Merino. In Genetics of Reproduction in Sheep, pp. 217-235, Eds R. B. Land \& D. W. Robinson, Butterworth Scientific, London.

Bister, J.-L. \& Paquay, R. (1983) Fluctuations in the plasma levels of the follicle-stimulating hormone during estrous cycle, anestrus, gestation and lactation in the ewe: evidence for an endogenous rhythm of FSH release. Theriogenology $19,565-583$.
Cahill, L.P. \& Mauléon, P. (1980) Influences of seuson, cycle and breed on the follicular growth rates in sheep. J. Reprod. Fert. 58, 321-328.

Cahill, L.P., Saumande, J., Ravault, J.P., Blanc, M., Thimonier, J., Mariana, J.C. \& Mauleon, P. (1981) Hormonal and follicular relationships in ewes of high and low ovulation rates. J. Reprod. Ferl. 62, 141150

Campbell, B.K. (1988) Factors affecting ovulation rate in sheep and cattle. Ph.D. thesis, University of Sydney:

Campbell, B.K., McNeilly, A.S., Picton, H.M. \& Baird, D.T. (1990a) The effect of a potent Gin-RH antagonist on ovarian secretion of oestradiol. inhibin and androstenedione and the concentration of $\mathrm{LH}$ and FSH during the follicular phase of the sheep oestrous cycle. J. Endocr. 126, 377-384.

Campbell, B.K., Mann, G.E., MeNeilly A.S. \& Baird, D.T. (1990b) The pattern of ovarian inhibin, estradiol and androstenedione secretion during the estrous cycle of the cwe. Endocrinology 127, 227-235.

Cummins, L.J., O'Shea, T., Al-Obaidi, S.A.R., Bindon, B.A. \& Findlay, J.K. (1986) Increase in ovulation rate after immunization of Merino ewes with a fraction of bovine follicular fluid containing inhibin activity, $J$. Reprod, Fert, 77, 365-372.

Dott, H.M., Hay, M.F., Cran, D.G. \& Moor, R.M. (1979) Effect of exogenous gonadotrophin (PMSG) on the antral follicle population in the sheep. $J$. Reprod. Fert. 56, 683-689.

Driancourt, M.A. \& Fry, R.C. (1989) Mechanisms involved in the control of the differentiation of the ovulatory follicle in sheep. J. Reprod. Fert., Abstr. Ser. 3, Abstr. 54.

Driancourt, M.A., Gauld, I.K., Terqui, M. \& Webb, R. (1986) Variations in patterns of follicle development in prolific breeds of sheep. J. Reprod. Fert. 78, 565-575.

Driancourt, M.A., Philipon, P., Locatelli, A., Jacques, E. \& Webb, R. (1988) Are differences in FSH concentration involved in the control of ovulation rate in Romanov and lle-de-France ewes? .7. Reprod. Fert. 83, 509-516, 
Dufour, J., Cahill, L.P. \& Mauléon, P. (1979) Short- and long-term effects of hypophysectomy and unilateral ovariectomy on ovarian follicular populations in sheep. J. Reprod. Ferl, 57, 301-309.

Findlay, J.K. \& Cumming, I.A. (1976) FSH in the ewe: effects of season, live weight and plane of nutrition on plasma FSH and ovulation rate. Biol. Reprod. 15, $335-342$.

Findlay, J.K. \& Cumming, I.A. (1977) The effect of unilateral ovariectomy on plasma gonadotropin levels, estrus and ovulation rate in sheep. Biol. Reprod. 17, 178-183.

Henderson, K.M., Franchimont, P., Lecomte-Yerna, M.J., Hudson, N. \& Ball, K. (1984) Increase in ovulation rate after active immunization of sheep with inhibin partially purified from bovine follicular fluid. J. Endoer. 102, 305-309.

Henderson, K.M., Kieboom, L.E., MeNatty, K.P., Lun, S. \& Heath, D. (1985) Gonadotrophin-stimulated cyclic AMP production by granulosa cells from Booroola $x$ Romney ewes with and without a fecundity gene. $J$. Reprod. Fert. 75, 111-120.

Henderson, K.M., Prisk, M.D., Hudson, N., Ball, K., McNatty, K.P., Lun, S., Heath, D., Kieboom, L.E. \& McDiarmid, J. (I986) Use of bovine follicular fluid to increase ovulation rate or prevent ovulation in sheep. J. Reprod. Fert. 76, 623-635.

Henderson, K.M., MeNatty, K.P., Smith, P., Gibb, M., O'Keefe, L.E., Lun, S., Heath, D.A. \& Prisk, M.D. (1987) Influence of follicular health on the steroidogenic and morphological characteristics of bovine granulosa cells in vitro. J. Reprod. Fert. 79, 185-193.

Henderson, K.M., Savage, L.C., Ellen, R.L., Ball, K. \& McNatty, K. P. (1988) Consequences of increasing or decreasing plasma FSH concentrations during the preovulatory period in Romney ewes. $J$. Reprod. Fert. 84, 187-196.

Hsueh, A.J.W., Adashi, E.Y., Jones, P.B.C. \& Welsh, T.H. (1984) Hormonal regulation of the differentiation of cultured ovarian granulosa cells. Endocrine Reviews 5, 76-127.

Hunter, M.G., Hindle, J.E., McLeod, B.J. \& McNeilly, A.S. (1988) Treatment with bovine follicular fluid suppresses follicular development in gonadotrophinreleasing hormonc-treated anoestrous ewes. J. Endocr. 119, 95-100.

Lahlou-Kassi, A., Schams, D. \& Glatzel, P. (1984) Plasma gonadotrophin concentrations during the oestrous cycle and after ovariectomy in two breeds of sheep with low and high fecundity. $J$. Reprod. Fert. 70, I65-173

Martin, G.B. \& Scaramuzzi, R.J. (1983) The induction of oestrus and ovulation in seasonally anovular ewes by exposure to rams. J. Steroid Biochem. 19, 869-875.

Mauléon, P. \& Mariana, J.C. (1977) Oogenesis and folliculogenesis. In Reproduction in Domestic Animals, pp. 175-202. Eds H. H. Cole \& P. T. Cupps. Academic Press, New York

McLeod, B.J. \& McNeilly, A.S. (1987) Suppression of plasma FSH concentrations and bovine follicular fluid blocks ovulation in GnRH-treated seasonally anoestrous ewes. J. Reprod. Fert. 81, 187-194.

McLeod, B.J., Haresign, W. \& Lamming, G.E. (1982a) The induction of ovulation and luteal function in seasonally anoestrous ewes treated with small-dose multiple injections of GnRH. J. Reprod. Fert. 65 , 215-221.

McLeod, B.J., Haresign, W, \& Lamming, G.E. (1982b) Response of seasonally anoestrous ewes to smalldose multiple injections of GnRH with and without progesterone pretreatment, J. Reprod. Fert. 65, 223-230.

McNatty, K.P., Gibb, M., Dobson, C., Ball, K., Coster, J., Heath, D. \& Thurley, D.C. (1982) Preovulatory follicular development in sheep treated with PMSG and/or prostaglandin. J. Reprod. Fert. 65, 111-123.

McNatty, K.P., Hudson, N., Gibb, M., Ball, K., Fannin, J., Kieboom, L. \& Thurley, D.C (1984a) Effects of long-term treatment with $\mathrm{LH}$ on induction of cyclic ovarian activity in seasonally anoestrous ewes. $J$. Endoct. 100, 67-73.

McNatty, K.P., Hudson, N.L., Henderson, K.M., Lun, S., Heath, D.A., Gibb, M., Ball, K., MeDiarmid, J.M. \& Thurley, D.C. (1984b) Changes in gonadotrophin secretion and ovarian antral follicle activity in seasonally breeding sheep throughout the year. $J$. Reprod. Fert. 70, 309-321.

MeNatty, K.P., Henderson, K.M., Lun, S., Heath, D.A., Ball, K., I Hudson, N.L., Fannin, J., Gibb, M., Kieboom, L.E. \& Smith, P. (1985a) Ovarian activity in Booroola $\times$ Romney ewes which have a major gene influencing their ovulation rate. J. Reprod. Fert. $73,109-120$

MeNatty, K.P., Hudson, N., Gibb, M., Ball, K., Henderson, K.M., Heath, D.A., Lun, S. \& Kieboom, L.E. (1985b) FSH influences follicle viability, oestradiol biosynthesis and ovulation rate in Romney ewes. J. Reprod. Fert. 75, 121-131.

McNatty, K.P., Lun, S., Heath, D.A., Ball, K., Smith, P., Hudson, N.L., McDiarmid, J., Gibb, M. \& Henderson, K.M. (1986) Differences in ovarian activity between Booroola $\times$ Merino ewes which were homozygous, heterozygous and non-carriers of a major gene influencing their ovulation rate. $J$. Reprod. Fert. 77, 193-205.

MeNatty, K.P., Fisher, M., Collins, F., Hudson, N.L., Heath, D.A., Ball, K. \& Henderson, K.M. (1989) Differences in the plasma concentrations of FSH and L.H in ovariectomized Booroola FF and ++ ewes. $J$. Reprod. FerI: 85, 705-713.

MeNeilly, A.S. (1984) Changes in FSH and the pulsatile secretion of LH during the delay in oestrus induced by treatment of ewes with bovine follicular fiuid. $J$. Reprod. Fert. 72, 165-172.

McNeilly, A.S. (1985) Effect of changes in FSH induced by bovine follicular fluid infusion in the preovulatory phase on subsequent ovulation rate and corpus luteum function in the ewe. J. Reprod. Fert. 74, 661-668.

MeNeilly, A.S. \& Fraser, H.M. (1987) Effect of GnRH agonist-induced suppression of LH and FSH on follicle growth and corpus luteum function in the ewe. $J$. Endocr. 115, 273-282.

McNeilly, A.S. \& Land, R.B. (1979) Effect of suppression of plasma prolactin on ovulation, plasma gonadotrophins and corpus luteumfunction in LHRH-treated anoestrous ewes. J. Reprod. Fert, 56, 601-609.

MeNeilly, A.S., O'ConnelI, M. \& Baird, D.T. (1982) Induction of ovulation and normal luteal function by 
pulsed injections of luteinizing hormone in anestrous ewes. Endacrinalogy 110, 1292-1299.

MeNeilly, A.S., Fraser, H.M. \& Baird, D.T. (1984) Effect of immunoneutralization of $\mathrm{LH}$ releasing hormone on LH, FSH and ovarian steroid secretion in the preovulatory phase of the oestrous cycle in the ewe. $J$. Endocr. 101, 213-219.

McNeilly, A.S., Wallace, J.M. \& Baird, D.T. (1985) Induction of ovulation in anoestrus ewes using gonadotrophins. In Endocrine Causes of Seasonal and Lactational Anoestrus In Farm Animals, pp. 66-676. Eds F. Elendorff \& F. Elsaesser. Martinus Nijhoff Publishers, The Hague.

McNeilly, A.S., Jonassen, J.A. \& Fraser, H.M. (1986) Suppression of follicular development after chronic LHRH immunoneutralization in the ewe. $J$. Reprod. Fert. 76, 481-490.

McNeilly, A.S., Jonassen, J.A. \& Rhind, S.M. (1987) Reduced ovarian follicular development as a consequence of low body condition in ewes. Acta endocr., Copenh. 115, 75-83.

Monniaux, D., Chupin, D. \& Saumande, J. ( I983) Superovulatory responses of cattle. Theriogenology 19 , 55-81.

Picton, H.M. (1989) The gonadotrophic control of ovarian follicle growth in the ewe. Ph.D. thesis, University of Edinburgh.

Picton, H.M., Tsonis, C.G. \& McNeilly, A.S. (1990a) FSH causes a time-dependent stimulation of preovulatory follicle growth in the absence of pulsatile LH secretion in ewes chronically treated with gonadotrophin-releasing hormone releasing hormone. $J$. Endocr. 126, 297-307.

Picton, H.M., Tsonis, C.G. \& MeNeilly, A.S. (1990b) The antagonistic effect of exogenous $\mathrm{LH}$ pulses on FSH-stimulated preovulatory follicle growth in ewes chronically treated with GnRH agonist. J. Endocr. (in press).

Rhind, S.M. \& McNeilly, A.S. (1986) Follicle populations, ovulation rates and plasma profiles of LH, FSH and prolactin in Scottish blackface ewes in high and low levels of body condition. Anim. Reprod. Sci. 10, $105-115$.

Robinson, T.J. (1959) The oestrous cycle of the ewe and doe. In Reproduction in Domestic Animals, Vol. 2, pp. 291-333. Eds H. H. Cole \& P. T. Cupps. Academic Press, New York.

Savio, J.D., Keenan, L., Boland, M.P. \& Roche, J.F. (1988) Pattern of growth of dominant follicles during the oestrous cycle of heifers. J. Reprod. Fert. 83, 663-671.

Scaramuzzi, R.J. \& Hoskinson, R.M. (1984) Active immunization against steroid hormones for increasing fecundity. In Immunological Aspects of Reproduction in Mammals, pp. 445-474. Ed. D. B. Crighton. Butterworths Scientific, London.
Scaramuzzi, R.J. \& Radford, H.M. (1983) Factors regulating ovulation rate in the ewe. J. Reprod. Fert. 69, 353-367.

Sirois, J. \& Fortune, J.E. (1988) Ovarian follicular dynamics during the estrous cycle in heifers monitored by real-time ultrasonography, Biol, Reprod.39, 308-317.

Thomas, G.B., Oldham, C.M., Hoskinson, R.M., Scaramuzzi, R.J. \& Martin, G.B. (1987) Effect of immunization against progesterone on oestrus, cycle length, ovulation rate, luteal regression and L.H secretion in the ewe. Aust, J. biol. Sci. 40, 307-313.

Tsonis, C.G., Cahill, L.P., Carson, R.S. \& Findlay, J.K. (I984) Identification at the onset of luteolysis of follicles capable of ovulation in the ewc. $J$, Reprod. Fert. $70,609-614$

Turnbull, K.E., Braden, A.W.H. \& Mattner, P.E. (1977) The pattern of follicular growth and atresia in the ovine ovary, Aust, J. biol. Sci. 30, 229-241.

Wallace, J.M. \& McNeilly, A.S. (1985) Increase in ovulation rate after treatment of ewes with bovine follicular fluid in the luteal phase of the oestrous cycle. J. Reprod. Fert. 73, 505-513.

Wallace, J.M. \& McNeilly, A.S. (1986) Changes in FSH and the pulsatile secretion of $\mathrm{LH}$ during treatment of ewes with bovine follicular fluid throughout the luteal phase of the oestrous cycle. J. Endocr. 111, 317-327.

Wallace, J.M., McNeilly, A.S. \& Baird, D.T. (1985) Ovulation răte and embryo survival in Damline ewes after treatment with bovine follicular fluid in the luteal phase of the oestrous cycle. J. Reprod. Fert. 75. 101-109,

Wallace, J.M., McNeilly, A.S. \& Baird, D.T. (1986) Induction of ovulation during anoestrus in two breeds of sheep with multiple injections of LH alone or in combination with FSH. J. Endocr. 111, $181-190$.

Wallace, J.M., Martin, G.B. \& McNeilly, A.S. (1988) Changes in the secretion of $\mathrm{LH}$ pulses, FSH and prolactin during the preovulatory phase of the oestrous cycle of the ewe and the influence of treatment with bovine follicular fluid during the luteal phase. $J$. Endocr. 116, 123-135.

Webb, R. \& Gauld, I.K. (1985) Genetics and physiology of follicle recruitment and maturation during seasonal anoestrus. In Endocrine Causes of Seasonal and Lactational Anoestrus in Furm Animals, pp. 19-28. Eds F. Ellendorff \& F. Elsaesser. Martinus Nijhoft Publishers. The Hague.

Webb, R., Gauld, I.K. \& Driancourt, M.A. (1989) Morphological and functional characteristics of large antral follicles in three breeds of sheep with different ovulation rates. J. Reprod. Fert . 87, 243-255. 